\title{
Effects of sera, hormones and granulosa cells added to culture medium for in-vitro maturation, fertilization, cleavage and development of bovine oocytes
}

\author{
Y. Fukui and H. Ono \\ Department of Meat Animal Reproduction, Obihiro University of Agriculture \\ and Veterinary Medicine, Obihiro 080, Japan
}

\begin{abstract}
Summary. Sera (fetal calf serum: FCS; and oestrous cow serum: ECS), hormones $(2 \cdot 5 \mathrm{FSH} \mu \mathrm{g} / \mathrm{ml}+5 \mu \mathrm{g} \mathrm{LH} / \mathrm{ml}+1 \mu \mathrm{g}$ oestradiol $/ \mathrm{ml})$ and granulosa cells $\left(5 \times 10^{6} / \mathrm{ml}\right)$ were added to culture medium to determine the frequencies of in-vitro maturation, fertilization, cleavage (2- to 8-cell) and development into blastocysts of bovine follicular oocytes. The maturation rates after $24 \mathrm{~h}$ in culture were not significantly different among the three factors tested $(56-72 \%)$. The fertilization rates were significantly affected by serum type and the addition of granulosa cells. FCS gave significantly higher rates of fertilization $(57-71 \%)$ than did ECS (34-52\%), but the proportions of polyspermic fertilization were significantly higher in the former $(8-19 \%)$ than in the latter $(2-3 \%)$. The addition of hormones did not affect fertilization, cleavage and development. Neither type of serum affected cleavage and development. The highest rates of blastocyst formation were obtained when granulosa cells alone were added (FCS, $17 \%$; ECS, $16 \%$ ). The cell numbers of the blastocysts obtained were 100-150, similar to those of blastocysts developed in vivo. Transfer of 6 blastocysts to 3 cows resulted in 1 pregnancy. The present results indicate that the co-culture with granulosa cells is the most important factor for in-vitro fertilization to development into blastocysts of bovine oocytes matured in vitro.
\end{abstract}

Keywords: cattle; oocyte; in-vitro fertilization; embryonic development

\section{Introduction}

To induce full maturation of the nucleus and cytoplasm in bovine follicular oocytes, several important factors, such as additions of follicle-stimulating hormone (FSH), luteinizing hormone (LH), oestradiol, granulosa cells, and serum from oestrous cow serum to the culture medium, have to be considered. Although the use of LH in culture medium did not affect the completion of maturation, the fertilizability and normal development of extrafollicular oocytes were increased (Moor \& Trounson, 1977; Shalgi et al., 1979). Steroids, especially oestradiol, improve the completion of maturation changes, including the synthesis of the presumed male pronucleus growth factor in both the nucleus and cytoplasm of mammalian oocytes (Thibault et al., 1975; Moor, 1978; Moor et al., 1980; Fukui et al., 1982). Fukushima \& Fukui (1985) reported that the addition of FSH, LH and oestradiol to a medium improved the fertilizability of extrafollicular bovine oocytes cultured in vitro. A favourable effect of serum from oestrous cows on bovine oocyte maturation in vitro has also been reported (Sanbuissho \& Threfall, 1985; Lu et al., 1987, 1988; Xu et al., 1987), although fetal calf serum (FCS) is routinely used in culture media for oocyte maturation. Furthermore, Critser et al. (1986) and Lutterbach et al. (1987) have shown that the granulosa cell interactions with cumulus-oocyte complexes during maturation in vitro are involved in imparting 
developmental competence to the maturing bovine oocytes. However, there are few reports investigating these factors on maturation of follicular oocytes of cattle. The present study was carried out to evaluate whether serum, hormones and granulosa cells and their interactions affect the frequency of maturation, fertilization, cleavage and development in vitro of follicular oocytes of cattle.

\section{Materials and Methods}

Materials. Ovaries were obtained from Holstein cows and heifers killed at a local abattoir and were transported in saline $(9 \mathrm{~g} \mathrm{NaCl} / \mathrm{l})$ at $30-35^{\circ} \mathrm{C}$ to the laboratory within $1 \mathrm{~h}$. The cumulus-oocyte complexes were collected from follicles of $2-5 \mathrm{~mm}$ in diameter with an 18-gauge needle attached to a $10-\mathrm{ml}$ disposable syringe. Only oocytes with an unexpanded cumulus oophorus and evenly granulated cytoplasm were cultured in a 30-mm plastic dish (Sterilin, Middlesex, UK; 20-30 oocytes/dish) containing $2 \mathrm{ml}$ TCM 199 (Whittaker M. A. Bioproducts, Walkersville, MD, USA; pH 7.4, Earle's salt with sodium bicarbonate and L-glutamine) supplemented with $20 \%(\mathrm{v} / \mathrm{v})$ heat-inactivated $\left(56^{\circ} \mathrm{C}, 30 \mathrm{~min}\right) \mathrm{FCS}$ or serum from oestrous cows (Lu et al., 1987). The medium was also supplemented with $2.5 \mu \mathrm{g}$ bovine FSH-B-1/ml (U.S. Department of Agriculture, USA); $5 \mu \mathrm{g}$ bovine LH-B-5/ml (National Hormone and Pituitary Program, USA) and $1 \mu \mathrm{g}$ oestradiol/ml (Sigma Chemical Co., St Louis, MO, USA) or with $5 \times 10^{6}$ granulosa cells $/ \mathrm{ml}$. The cells were collected from antral follicles of about $10 \mathrm{~mm}$ in diameter after dissection by the method of Moor \& Trounson (1977) and washed $(400 \mathrm{~g}, 5 \mathrm{~min}) 3$ times with TCM $199+10 \%(\mathrm{v} / \mathrm{v})$ FCS or oestrous cow serum $+25 \mathrm{~mm}$-Hepes (Sigma Chemical $\mathrm{Co}$.). In each experiment, 8 different media for oocyte maturation were prepared according to the factors examined (two sera, the presence or absence of hormones and granulosa cells). Oocytes were allocated to 8 Petri dishes and were statically cultured for $24 \mathrm{~h}$ at $39^{\circ} \mathrm{C}$ under $5 \% \mathrm{CO}_{2}$ in air and $95 \%$ humidity.

Insemination. Three $0 \cdot 5-\mathrm{ml}$ frozen straws of semen from a Holstein bull were thawed at $35^{\circ} \mathrm{C}$ and were prepared for sperm capacitation. The thawed semen $(0.2 \mathrm{ml}$ each) was layered under $1 \mathrm{ml}$ modifed Tyrode's calcium-free medium ( $\mathrm{pH}$ 7.4: capacitation medium) in conical tubes for a swim-up procedure (Parrish et al., 1986; Lu et al., 1987). The top $0.8 \mathrm{ml}$ medium was then collected after incubation for $1 \mathrm{~h}$ at $39^{\circ} \mathrm{C}$. The pooled medium containing spermatozoa was washed twice $(400 \mathrm{~g}, 10 \mathrm{~min})$ with the capacitation medium. The final pellet of semen was re-suspended with the medium to the concentration of $50 \times 10^{6} \mathrm{spermatozoa} / \mathrm{ml}$. An equal volume of a $200 \mu \mathrm{g}$-heparin $/ \mathrm{ml}$ (Sigma) solution was added to the semen suspension to yield sperm and heparin concentrations of $25 \times 10^{6} \mathrm{cells} / \mathrm{ml}$ and $100 \mu \mathrm{g} / \mathrm{ml}$, respectively. The heparin-treated spermatozoa were incubated for $15 \mathrm{~min}$ at $39^{\circ} \mathrm{C} \mathrm{in} 5 \% \mathrm{CO}_{2}$ in air.

Oocyte cultures. One third of the oocytes cultured for $24 \mathrm{~h}$ in each dish were fixed (acetic acid and alcohol, 1:3, v/v) and stained with $1 \%$ aceto-orcein for maturation (the second metaphase). The remaining oocytes were washed 3 times with a modified Tyrode's medium ( $\mathrm{pH}$ 7.4: washing medium) containing $2 \mathrm{~mm}-\mathrm{CaCl}_{2}$ and $2 \mathrm{~mm}-\mathrm{NaHCO}_{3}$ (Parrish et al., 1986), and the surrounding cumulus cells were partly removed by gentle pipetting. Eight groups of oocytes were separately allocated to in-vitro fertilization as follows. Washing medium, $2 \mu \mathrm{l}$ containing 5 oocytes in each group, was placed into 46- $\mu$ l drops of a modified Tyrode's fertilization medium (pH 7.8, Parrish et al., 1986) under sterile oil (Nakarai Chemical Co., Tokyo, Japan). Then $2 \mu \mathrm{l}$ of the heparin-treated spermatozoa were added to the oocytes to give a final sperm concentration of $1 \times 10^{6} \mathrm{cells} / \mathrm{ml}$. After in-vitro insemination, oocytes and spermatozoa were incubated for $18-20 \mathrm{~h}$ at $39^{\circ} \mathrm{C}$ under $5 \% \mathrm{CO}_{2}$ in air. After the incubation, about half of the oocytes were fixed and stained for evidence of fertilization. Oocytes were considered as being fertilized when the female and male pronuclei with residual sperm tail(s) were visible. The remaining oocytes were cultured for another 3 days in the same droplets to evaluate cleavage (2- to 8 -cell).

Development. For examining the developmental capacity to blastocysts, the same procedures for in-vitro maturation and fertilization were carried out. At $18-20 \mathrm{~h}$ after insemination, all embryos in the 8 different groups were transferred to a co-culture medium (TCM $199+10 \%(\mathrm{v} / \mathrm{v})$ oestrous cow serum) with bovine oviduct epithelial cells (Fukui \& Ono, 1988). These cells were collected by flushing the oviducts of cows and heifers that had a newly-formed corpus luteum with $10 \mathrm{ml}$ Dulbecco's phosphate-buffered saline containing $10 \%$ (v/v) FCS per oviduct. The flushed fluid was kept at $39^{\circ} \mathrm{C}$ for $10 \mathrm{~min}$ and the supernatant was carefully removed. After re-suspension with TCM $199+10 \%$ (v/v) oestrous cow serum, a $0 \cdot 5-\mathrm{ml}$ sample of the cell suspension was placed into the 4-well dishes (Nunclon, Inter-Med., Denmark). Then 10 embryos in each well were cultured for 7 days at $39^{\circ} \mathrm{C}$ under $5 \% \mathrm{CO}_{2}$ in air, and the medium was replaced every 3 days with fresh medium. After 7 days in culture, numbers of expanding and expanded blastocysts were recorded.

Factorial studies with serum (FCS and oestrous cow serum), hormones (FSH + LH + oestradiol and none) and granulosa cells (with and without) were designed as $2 \times 2 \times 2$ (8 experiments) treatments with $8-10$ replicates in each experiment. The proportions of in-vitro matured, fertilized, cleaved and developed eggs were subjected to least-square methods for analysis of variance after angular transformation (Steel \& Torrie, 1960). Fisher's Exact Tests as described by Bradley (I968) were also performed to compare the interactions of the factors examined. The $5 \%$ level of significance was used for statistical analyses.

Cell numbers. Some expanding and expanded blastocysts that developed in vitro were examined for the number of cells by the method of Ushijima et al. (1988). Briefly, embryos were treated with $0.9 \%(\mathrm{v} / \mathrm{v})$ sodium citrate for 
10-20 min, and fixed with a solution of alcohol:acetic acid:distilled water $\left(3: 2: 1\right.$ by vol.) at $4^{\circ} \mathrm{C}$ for $1 \mathrm{~min}$. The fixed embryos were placed on slides with a small volume of the fixative, dried for up to $1 \mathrm{~h}$ and stained by $10 \%(\mathrm{w} / \mathrm{v})$ Giemsa solution for $15 \mathrm{~min}$. The cell numbers were determined under a phase-contrast microscope. The mean \pm s.e. cell numbers were compared by Student's $t$ test for the different culture conditions.

Viability. To evaluate the viability of blastocysts that developed, 6 blastocysts were non-surgically transferred into the uterus of 3 recipients ( 2 embryos/recipient) at Day 6-7 after natural oestrus.

\section{Results}

The mean rates of maturation to the second metaphase in the 2 serum types in the present study (Table 1) did not differ significantly. The additions of hormones and granulosa cells also did not show significant differences. However, there were significant differences in the maturation rates when granulosa cells were added in the FCS group (72 and 71\%) compared with addition of hormones and granulosa cells in the other group $(56 \%)$. There was also a significant $(P<0.05)$ interaction in the maturation rate between the sera and granulosa cells. Analysis of variance showed that the fertilization rates (Table 1$)$ were significantly $(P<0.001)$ affected by the sera and the addition of granulosa cells. The use of FCS resulted in significantly $(P<0.001)$ higher rates of fertilization and of polyspermic fertilization (Table 1). Fertilization rate was significantly $(P<0.05)$ higher than in any other group when granulosa cells were added to cultures with FCS.

Table 1. Effects of serum, (FCS or oestrous cow serum, ECS), hormones $(2.5 \mu \mathrm{g} \mathrm{FSH} / \mathrm{ml}, 5 \mu \mathrm{g} \mathrm{LH} / \mathrm{ml}$, $1 \mu \mathrm{g}$ oestradiol $/ \mathrm{ml})$ and granulosa cells $\left(5 \times 10^{6} / \mathrm{ml}\right)$ added to culture media on in-vitro maturation and fertilization of bovine oocytes

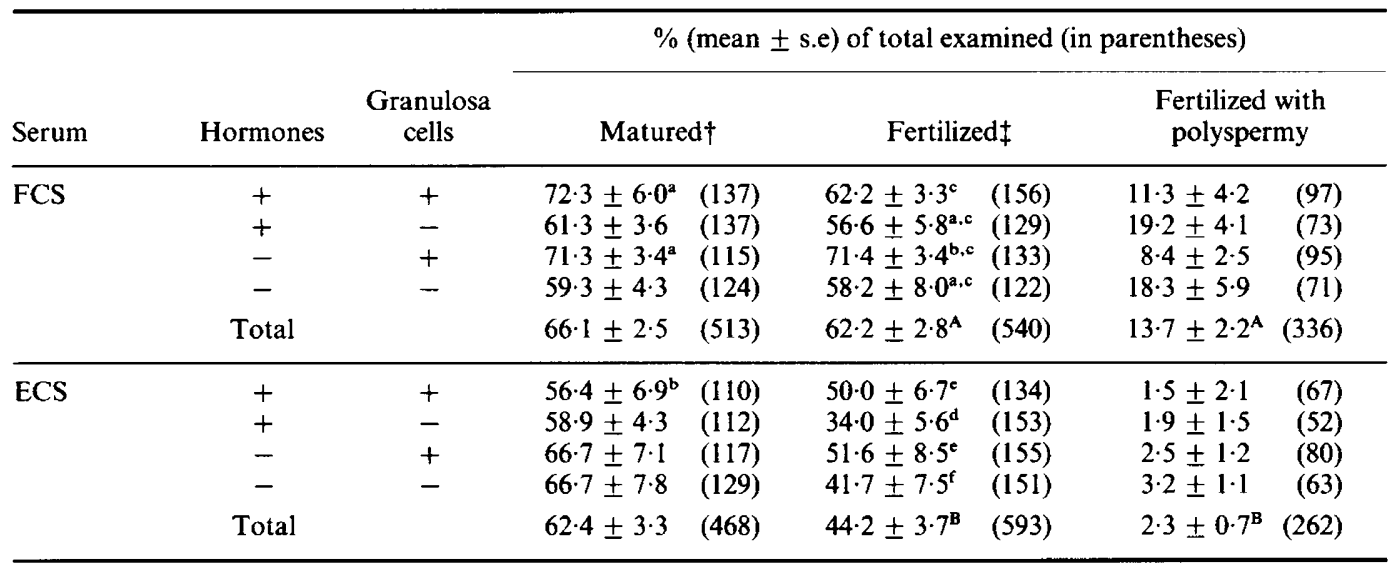

†Percentage of the number of oocytes matured to the second metaphase.

$\$$ Percentage of the number of oocytes fertilized with two pronuclei and a sperm tail.

$P<0.05$ for a $v s \mathrm{~b} \& \mathrm{f} ; \mathrm{b} v s \mathrm{~d}$, e \& $\mathrm{f} ; \mathrm{d} v s \mathrm{c} \& \mathrm{e} ; \mathrm{f} v s \mathrm{c}$.

$P<0.001$ for A vs B.

Analysis of variance showed that the serum type did not affect cleavage or development into blastocysts (Table 2). The addition of hormones in both groups tended to reduce cleavage rates and there was a significant $(P<0.05)$ effect on cleavage rate when granulosa cells were added. Development into blastocysts was significantly $(P<0.001)$ affected by the addition of granulosa cells, but not by the serum or hormones. There were significant interactions between the additions of hormones and granulosa cells $(P<0.001)$, and among the three factors $(P<0.05)$ examined.

The numbers of cells in expanding/expanded blastocysts developed in vitro in the present study are shown in Table 3. Oocytes cultured with granulosa cells with or without hormones had more cells per blastocyst than did those cultured without granulosa cells, but the difference was not significant. 
Table 2. Effects of serum (FCS or oestrous cow serum, ECS), hormones $(2 \cdot 5 \mu \mathrm{g} \mathrm{FSH} / \mathrm{ml}, 5 \mu \mathrm{g} \mathrm{LH} / \mathrm{ml}, 1 \mu \mathrm{g}$ oestradiol $/ \mathrm{ml})$ and granulosa cells $\left(5 \times 10^{6} / \mathrm{ml}\right)$ added to culture media on in-vitro cleavage and development into blastocysts of bovine oocytes

\begin{tabular}{lcccccc}
\hline & & \multicolumn{4}{c}{$\%$ (mean \pm s.e) of total examined } \\
(in parentheses)
\end{tabular}

$P<0.05$ for a $v s \mathrm{~b} ; \mathrm{d} v s \mathrm{~b}, \mathrm{c} \& \mathrm{e}$.

Table 3. The number of cells in expanding/ expanded blastocysts developed in vitro in serum, (FCS and ECS values pooled) in the presence of hormones $(2.5 \mu \mathrm{g} \mathrm{FSH} / \mathrm{ml}, 5 \mu \mathrm{g} \mathrm{LH} / \mathrm{ml}, 1 \mu \mathrm{g}$ oestradiol $/ \mathrm{ml})$ or granulosa cells $\left(5 \times 10^{6} / \mathrm{ml}\right)$

\begin{tabular}{lccc}
\hline Hormones & $\begin{array}{c}\text { Granulosa } \\
\text { cells }\end{array}$ & $\begin{array}{c}\text { No. of } \\
\text { embryos } \\
\text { examined }\end{array}$ & $\begin{array}{c}\text { No. of cells/ } \\
\text { blastocyst } \\
\text { (mean } \pm \text { s.e.) }\end{array}$ \\
\hline+ & + & 15 & $134 \pm 11 \cdot 1$ \\
+ & - & 2 & $100 \pm 11 \cdot 5$ \\
- & + & 15 & $150 \pm 10 \cdot 7$ \\
- & - & 2 & $124 \pm 16.0$ \\
\hline
\end{tabular}

After transfers to evaluate the viability of blastocysts, 1 of the 3 recipients was pregnant at 180 days.

\section{Discussion}

It has been reported that the presence of granulosa cells for oocyte maturation in vitro has a positive effect on full maturation (Thibault et al., 1987), normal fertilization and further development in rabbit (Motlík \& Fulka, 1981), pig (Fulka \& Motlík, 1980) and sheep (Staigmiller \& Moor, 1984). Several workers (Critser et al., 1986; Lu et al., 1987, 1988; Lutterbach et al., 1987; Xu et al., 1987; Fukui \& Ono, 1988) have also used granulosa cells to induce nuclear and cytoplasmic maturation of bovine oocytes, and suggested that these cells enhanced the rate of fertilization and the subsequent developmental capacity of the oocytes. The present results confirm the previous studies, although the concentrations of granulosa cells used have differed in different studies (1-7 $\times$ $10^{6} \mathrm{cells} / \mathrm{ml}$ ). Critser et al. (1986) obtained frequencies of maturation and fertilization in bovine oocytes co-cultured with granulosa cells $\left(1 \times 10^{6}\right.$ cells $\left./ \mathrm{ml}\right)$ that were similar to those for isolated 
cumulus-oocyte complexes, but morulae and blastocysts were observed only from the oocytes cultured with granulosa cells. Lutterbach et al. (1987) also used $1 \times 10^{6}$ granulosa cells/ml for maturation, and found higher rates of nuclear maturation and fertilization than for oocytes cultured alone in medium. Higher concentrations of granulosa cells were used by Lu et al. (1987) $\left(5-7 \times 10^{6}\right.$ cells $\left./ \mathrm{ml}\right)$, Xu et al. $(1987)\left(3 \times 10^{6}\right.$ cells $\left./ \mathrm{ml}\right)$, Fukui \& Ono $(1988)\left(5 \times 10^{6} \mathrm{cells} / \mathrm{ml}\right)$, and the present study. Ireland \& Roche (1983) compared hormonally and histologically classified bovine follicles, and found that oestrogen-active and healthy follicles have a greater number of granulosa cells without pycnotic nuclei than do oestrogen-inactive follicles $\left(8.5-8.6 \times 10^{6} \mathrm{vs}\right.$ $3 \times 10^{6} \mathrm{cells} / \mathrm{ml}$ ). Therefore, it would be important to select oestrogen-active, antral follicles for harvesting granulosa cells.

The possibility of achieving full maturation of extra-follicular oocytes in domestic animals has also been investigated by using gonadotrophins (FSH and LH) and steroid hormones (oestradiol and progesterone) in culture media (Moor \& Trounson, 1977; Fukushima \& Fukui, 1985; Karlach, 1986). Steroids, especially oestrogens, improve the completion of maturation changes in both the nucleus and cytoplasm of mammalian oocytes (Bae \& Foote, 1975; Moor, 1978; Moor et al., 1980; Fukui et al., 1982; Gradl et al., 1988). The addition of FSH, LH and oestradiol to culture media has been used for sheep (Moor \& Trounson, 1977; Moor, 1978; Moor \& Crosby, 1985) and cattle (Fukushima \& Fukui, 1985) oocytes. Moor \& Trounson (1977) showed in sheep that the addition of oestrogen together with FSH and LH resulted in the development of 26-50\% oocytes to blastocysts. In the present study, no positive effect of the additional hormones (FSH, LH and oestradiol) was found in the frequencies of maturation to blastocyst formation. The rates of fertilization, cleavage and development into blastocysts were impaired by the addition of those hormones, particularly when granulosa cells were absent. Although the reasons for this contradiction are not clear, the nature and doses of gonadotrophins and oestrogen, media and culture methods were different in the previous (Fukushima \& Fukui, 1985) and present studies. Stubbings et al. (1988) added oestradiol throughout maturation of bovine oocytes, and FSH and LH were added after culture for $6 \mathrm{~h}$ : significantly higher rates of fertilization and development into morulae were obtained than when all hormones were present from the start of culture. The oocyte in vivo is initially exposed to oestradiol, and then FSH and LH. Therefore, timing of the addition of FSH and LH should be taken into consideration, particularly for the culture of follicle-enclosed oocytes (Fukui et al., 1987).

Sanbuissho \& Threfall (1985) improved the fertilization rate of bovine oocytes cultured in vitro with serum from oestrous cows, but maturation rate was not improved. The present study showed that fetal calf serum was superior to oestrous cow serum although use of the latter gave lower frequencies of polyspermic fertilization. The causes of this difference are unclear. FCS is routinely used for oocyte maturation in mammals, but there is a considerable variation in commercial lots of FCS (Shiigi \& Mishell, 1975). The cow serum used in the present study was collected from cows at the time of artificial insemination during 'standing oestrus' at the University Farm, and pooled as a stock for the use throughout the study.

It has been reported that bovine blastocysts developed in vivo usually contained about 100, 120 and 160 cells at the early, expanding and expanded blastocyst stages, respectively (Mannaerts, 1986; Picard et al., 1986; Ushijima et al., 1988). Compared to blastocysts developed in vivo, the numbers of cells in the blastocysts developed in the present study were very similar. As shown by Lu et al. (1988), the co-culture of oocytes with bovine oviduct epithelial cells provides an appropriate environment for bovine embryonic development after in-vitro maturation and fertilization, and one recipient became pregnant after transfer of blastocysts developed in the present conditions.

We thank Dr S. Raiti and Dr D. J. Bolt for the supply of bovine LH and FSH, respectively. This study was partly supported by the Scientific Grant of the Ministry of Education, Japan (no. 62560255 ) and the Kuribayashi Scientific Foundation (Sapporo), Japan. 


\section{References}

Bae, I.H. \& Foote, R.H. (1975) Effects of hormones on the maturation of rabbit oocytes recovered from follicles of various sizes. J. Reprod. Fert. 42. 357-360.

Bradley, J.V. (1968) Distribution-free Statistical Test. Prentice-Hall, New Jersey.

Critser, E.S., Leibfried-Rutledge, M.L., Eyestone, W.H., Northey, D.L. \& First, N.L. (1986) Acquisition of developmental competence during maturation invitro. Theriogenology 25, 150, Abstr.

Fukui, Y. \& Ono, H. (1988) In-vitro development to blastocyst of in-vitro matured and fertilized bovine oocytes. Vet. Rec. 122, 282.

Fukui, Y., Fukushima, M., Terawaki, Y. \& Ono, H. (1982) Effect of gonadotropins, steroid and culture media on bovine oocyte maturation in-vitro. Theriogenology 18, 161-175.

Fukui, Y., Imai, K., Alfonso, N.F. \& Ono, H. (1987) Follicle culture enhances fertilization and cleavage of bovine oocytes matured in-vitro. J. Anim. Sci. 64, 935-941.

Fukushima, M. \& Fukui, Y. (1985) Effects of gonadotropins and steroids on the subsequent fertilizability of extrafollicular bovine oocytes cultured in-vitro. Anim. Reprod. Sci. 9, 323-332.

Fulka, J. \& Motlík, J. (1980) In-vitro maturation. Proc. 9th Int. Congr. Anim. Reprod. \& A.I., Madrid, Vol. II, pp. 55-62.

Gradl, E., Lutterbach, A. \& Brem, G. (1988) Influence of follicle cell coculture and $17 \beta$-estradiol on in-vitro maturation and fertilization of cattle oocytes. Proc. Ilth Int. Congr. Anim. Reprod. \& A.I., Dublin, Vol. 3, 329.

Ireland, J.J. \& Roche, J.F. (1983) Growth and differentiation of large antral follicles after spontaneous luteolysis in heifers: changes in concentration of hormones in follicular fluid and specific binding of gonadotropins to follicles. J. Anim. Sci. 57, 157-167.

Karlach, V. (1986) The effect of FSH, LH, oestradiol$17 \beta$, and progesterone on cytoplasmic maturation of bovine follicular oocytes in-vitro. Folia biol. (Praha) 33, 259-265.

Lu, K.H., Gordon, I., Gallagher, M. \& McGovern, H. (1987) Pregnancy established in cattle by transfer of embryos derived from in-vitro fertilization of oocytes matured in-vitro. Vet. Rec. 121, 259-260.

Lu, K.H., Gordon, I., Chen, H.B., Gallagher, M. \& McGovern, H. (1988) Birth of twins after transfer of cattle embryos produced by in-vitro techniques. Vet. Rec. 122, 539-540.

Lutterbach, A., Koll, R.A. \& Brem, G. (1987) In-vitro maturation of bovine oocytes in coculture and granulosa cells and their subsequent fertilization and development. Zuchthygiene 22, 145-150.

Mannaerts, B.M.J.L. (1986) Cytological parameters for rating bovine embryo quality. Cur. Top. Vet. Med. Anim. Sci. 34, 216-222.

Moor, R.M. (1978) Role of steroids in the maturation of ovine oocytes. Annls Biol. anim. Biochim. Biophys. 18, $477-482$.
Moor, R.M. \& Crosby, I.M. (1985) Temperature-induced abnormalities in sheep oocytes during maturation. $J$. Reprod. Fert. 75, 467-473.

Moor, R.M. \& Trounson, A.O. (1977) Hormonal and follicular factors affecting maturation of sheep oocytes in vitro and their subsequent developmental capacity. J. Reprod. Fert. 49, 101-109.

Moor, R.M., Polge, C. \& Willadsen, S.M. (1980) Effect of follicular steroids on the maturation and fertilization of mammalian oocytes. J. Embryol. exp. Morphol. 56, 319-335.

Molík, J. \& Fulka, J. (1981) Fertilization of rabbit oocytes co-cultured with granulosa cells. J. Reprod. Fert. 63, 425-429.

Parrish, J.J., Susko-Parrish, J.L., Leibfried-Rutledge, M.L., Critser, E.S., Eyestone, W.H. \& First, N.L. (1986) Bovine in-vitro fertilization with frozenthawed semen. Theriogenology 25, 591-600.

Picard, L., Greve, T., King, W.A., Betteridge, K.J. \& Holm Jorgensen, P. (1986) Bisection of post-compaction bovine embryos: the difference in viability between the two monozygotic halves. Acta vet. scand. 27, 33-48.

Sanbuissho, A. \& Threfall, W.R. (1985) The effects of estrous cow serum on the maturation and fertilization of the bovine follicular oocyte in-vitro. Theriogenology 23, 226, Abstr.

Shalgi, R., Dekel, N. \& Kraicer, P.F. (1979) The effect of LH on the fertilizability and developmental capacity of rat oocytes matured in vitro. $J$. Reprod. Fert. 55, 429. 435 .

Shiigi, S.M. \& Mishell, R.I. (1975) Sera and the in-vitro induction of immune responses. I. Bacterial contamination and the generation of good fetal bovine sera. J. Immunol. 115, 741-744.

Staigmiller, R.B. \& Moor, R.M. (1984) Effect of follicle cells on the maturation and developmental competence of ovine oocytes matured outside the follicle Gamete Res. 9, 221-229.

Steel, R.G.D. \& Torrie, J.H. (1960) Principles and Procedures of Statistics. McGraw-Hill, New York.

Stubbings, R.B., Betteridge, K.J. \& Basrur, P.K. (1988) Investigations of culture requirements for bovine oocyte maturation in-vitro. Theriogenology 29, 313, Abstr.

Thibault, C., Gérard, M. \& Menézo, Y. (1975) Preovulatory and ovulatory mechanisms in oocyte maturation. J. Reprod. Fert. 45, 605-610.

Thibault, C., Szöllösi, D. \& Gérard, M. (1987) Mammalian oocyte maturation. Reprod. Nutr. Devélop. 27, 865-896.

Ushijima, M., Okuda, T., Nakayama, A., Moji, K., Ishida, K., Murata, H., Iguchi, A. \& Etoh, T. (1988) Relationship between the cell number and quality of Day-8 bovine blastocysts. Proc. 3rd East. Jpn. Soc. Anim. Embryo Trans., no. 9, pp. 37-38, [In Japanese].

Xu, K.R., Greve, T., Callesen, H. \& Hyttel, P. (1987) Pregnancy resulting from cattle oocytes matured and fertilized in vitro. J. Reprod. Fert. 81, 501-504.

Received 20 September 1988 